\title{
Formulasi Tablet Effervescent dari Fraksi Etil Asetat Buah Kasturi (Mangifera Casturi Kosterm) Asal Kalimantan Selatan
}

\author{
Sutomo*, Najat Su'aida, Arnida \\ Program Studi Farmasi Fakultas MIPA Universitas Lambung Mangkurat \\ *Email korespondensi : sutomo01@ulm.ac.id
}

(Submit 15/03/2019, Revisi 05/09/2019, Diterima 20/12/2019)

\begin{abstract}
Abstrak
Kasturi (Mangifera casturi Kosterm) merupakan salah satu tumbuhan khas Kalimantan Selatan yang mengandung senyawa dengan aktivitas antioksidan. Mangifera casturi sangat berpotensi untuk dikembangkan, salah satunya sebagai suatu sediaan seperti tablet effervescent. Penelitian ini bertujuan untuk menentukan pengaruh variasi konsentrasi fraksi etil asetat buah $M$. casturi terhadap karakteristik tablet effervescent. Ekstrak buah $M$. casturi diperoleh dengan metode maserasi menggunakan pelarut etanol 96\% kemudian difraksinasi hingga didapatkan fraksi kental etil asetat. Variasi konsentrasi fraksi etil asetat yang digunakan antara lain : Formula 1 (125 mg), formula 2 (250 mg), dan formula 3 (500 mg). Masing-masing formula dibuat menggunakan metode kempa langsung dan dilakukan uji evaluasi berupa uji organoleptik, keseragaman bobot, kadar air, kekerasan tablet, waktu larut dan $\mathrm{pH}$, kemudian dianalisis dengan SPSS. Hasil evaluasi menunjukkan bahwa variasi fraksi etil asetat buah M.casturi memberikan pengaruh terhadap warna, kadar air, kekerasan tablet dan waktu larut tablet effervescent. Formula tablet effervescent yang mengandung konsentrasi $125 \mathrm{mg}$ fraksi etil asetat merupakan tablet yang paling baik dengan hasil evaluasi warna (coklat terang), kadar air $(4 \%)$, kekerasan tablet $(8 \mathrm{~kg})$, dan waktu larut (1,31 menit).
\end{abstract}

Kata kunci: Antioksidan, fraksi etil asetat, Mangifera casturi, tablet effervescent

\section{Outline}

- Pendahuluan

- Metode

- Hasil dan Pembahasan

- Kesimpulan

- Ucapan Terima Kasih

- Daftar Pustaka

\section{Pendahuluan}

Kasturi (Mangifera casturi Kosterm) merupakan salah satu tumbuhan khas Kalimantan Selatan yang berpotensi untuk dikembangkan. Salah satu potensi yang dimiliki $M$. casturi adalah sebagai antioksidan. Penelitian tentang aktivitas antioksidan dari buah $M$. casturi telah dilakukan. Penelitian tersebut meliputi, penelitian terhadap ekstrak metanol $^{1}$, fraksi $n$-heksan ${ }^{1}$, dan fraksi etil asetat ${ }^{2}$ dari buah $M$. casturi. Pada 
penelitian ini digunakan sampel fraksi etil asetat dari buah M. casturi. Fraksi etil asetat dari buah $M$. casturi memiliki aktivitas antioksidan dengan nilai $I_{50}$ sebesar $6 \mu \mathrm{g} / \mathrm{mL} 1$. Berdasarkan penjelasan di atas maka perlu dilakukan pengembangan untuk memanfaatkan potensi dari buah $M$. casturi. Pengembangan tersebut dapat dilakukan dengan membuat suatu sediaan seperti tablet effervescent. Sejauh ini belum diketahui formulasi yang tepat untuk pembuatan tablet effervescent dari fraksi etil asetat buah M. casturi. Oleh sebab itu, perlu dilakukan penelitian ini untuk menentukan pengaruh variasi konsentrasi fraksi etil asetat buah $M$. casturi terhadap karakteristik tablet effervescent sehingga didapatkan tablet effervescent dengan karakteristik yang baik dengan konsentrasi fraksi etil asetat yang sesuai. Pembuatan sediaan tablet effervescent ini diharapkan dapat meningkatkan penggunaan buah $M$. casturi sebagai obat tradisional berkhasiat antioksidan yang dapat digunakan di masyarakat.

\section{Metode}

\section{A. Alat dan Bahan}

Alat yang digunakan dalam penelitian ini adalah alat-alat gelas, ayakan no 16, blender, cawan porselin, corong pisah, hardness tester, maserator, mesin pencetak tablet, oven, $\mathrm{pH}$ meter, timbangan analitik, dan waterbath.

Bahan-bahan yang digunakan adalah buah $M$. casturi, aluminium foil, akuades, aspartam, asam sitrat, asam tartrat, etanol $70 \%$, etanol $96 \%$, etil asetat (p.a), laktosa, magnesium stearat, $n$-heksana, natrium bikarbonat, PVP, dan PEG 6000.

\section{B. Preparasi Sampel}

Buah M. casturi diambil dari daerah Martapura Kalimantan Selatan. Proses penyiapan simplisia buah $M$. casturi diawali dengan melakukan sortasi basah kemudian daging buah $M$. casturi bersama dengan kulit buah dipisahkan dari bijinya, dipotong kecil, dan dikeringkan dengan oven pada suhu $\pm 50^{\circ} \mathrm{C}$ kemudian disortasi kering dan dilakukan penyerbukan.

\section{Pembuatan Fraksi Etil Asetat buah M. casturi Kosterm}

Serbuk buah $M$. casturi $(1,528 \mathrm{~kg})$ diekstraksi dengan metode maserasi menggunakan cairan penyari etanol $96 \%$ kemudian dikentalkan dengahn rotary evaporator. Ekstrak kental buah $M$. casturi sebanyak 15 gram disuspensi dengan air (1:1) kemudian dilakukan fraksinasi menggunakan pelarut $n$-heksana, selanjutnya lapisan air difraksi kembali menggunakan pelarut etil asetat. Fraksi etil asetat dikentalkan sampai bobotnya tetap dan dihitung nilai rendemennya sebagai fraksi etil asetat ${ }^{3}$.

\section{Pembuatan Tablet Effervescent}

Tablet effervescent dibuat menjadi tiga formula Tabel 1 menggunakan metode kempa langsung. Fraksi etil asetat buah $M$. casturi dibuat menjadi serbuk dengan menambahkan sebagian pengikat PVP dan etanol 70\% 2-3 tetes menggunakan pipet pada fraksi etil asetat ke dalam mortir, kemudian ditambahkan laktosa sedikit demi sedikit dan digerus hingga homogen. Campuran dikeringkan dalam oven pada suhu $40^{\circ}-50^{\circ} \mathrm{C}$ selama 15 menit, setelah kering diayak dengan ayakan nomor 16 . Campuran kemudian ditambahkan dengan bahan tambahan lainnya dan setelah homogen ditambahkan magnesium stearat yang selanjutnya dicetak menggunakan pencetak tablet manual dengan bobot tiap tablet $1000 \mathrm{mg}$. 
Tabel 1. Formulasi tablet effervescent fraksi etil asetat buah M. casturi

\begin{tabular}{|l|c|c|c|}
\hline \multicolumn{1}{|c|}{ Bahan } & \multicolumn{3}{|c|}{ Jumlah (mg) } \\
\hline Fraksi & F1 & F2 & F3 \\
\hline Laktosa & 125 & 250 & 500 \\
\hline Asam sitrat & 475 & 350 & 100 \\
\hline Asam tartrat & 65 & 65 & 65 \\
\hline Na bikarbonat & 100 & 100 & 100 \\
\hline Mg stearat & 180 & 180 & 180 \\
\hline Aspartam & 20 & 10 & 10 \\
\hline PVP & 10 & 20 & 20 \\
\hline PEG 6000 & 15 & 10 & 10 \\
\hline Berat total & 1000 & 1000 & 15 \\
\hline & & & \\
\hline
\end{tabular}

\section{E. Evaluasi Tablet Effervescent}

i. Uji organoleptis

Uji organoleptis dilakukan dengan cara mengamati secara langsung dari tablet effervescent yang dihasilkan berupa bentuk, warna, bau, dan rasa ${ }^{4}$.

\section{ii. Uji kadar air}

Pertama-tama tablet ditimbang kemudian dioven dengan suhu $\pm 105^{\circ}-110^{\circ} \mathrm{C}$ selama 3 jam, selanjutnya dimasukkan ke dalam desikator selama 15 menit untuk pendinginan lalu ditimbang kembali. Tablet dipanaskan kembali dalam oven selama 15 menit dengan suhu yang sama kemudian ditimbang, perlakuan ini diulang sampai diperoleh berat yang konstan. Tablet effervescent dengan bahan herbal memiliki persyaratan kadar air maksimum $10 \%$.

iii. Uji keseragaman bobot

Sejumlah 10 tablet ditimbang secara seksama satu persatu, kemudian dihitung bobot rata-rata dan koefisien variasinya. Persyaratannya tidak satu tablet pun yang bobotnya menyimpang lebih besar dari bobot rata-rata yang ditetapkan kolom $A$ dan tidak satu tablet pun yang bobotnya menyimpang lebih dari harga yang ditetapkan kolom $\mathrm{B}^{6}$.

iv. Uji kekerasan tablet

Uji kekerasan tablet ini menggunakan alat bernama hardness tester, adapun alat hardnerss tester yang digunakan pada penelitian ini adalah monsanto tester yaitu jenis alat yang dioperasikan secara manual dengan cara tablet dimasukkan ke dalam alat kemudiaan diputar knop spiralnya hingga bagian bebannya menekan tablet sampai hancur dan didapatkan angka atau nilai kekerasan tablet tersebut. Kekerasan minimum yang sesuai untuk tablet adalah sebesar $4 \mathrm{~kg}^{4}$.

\section{v. Uji waktu larut}

Tablet effervescent dimasukkan ke dalam akuades dengan volume $100 \mathrm{~mL}$ dan dihitung waktu larutnya menggunakan stopwatch yang dimulai dari tablet tercelup sampai semua tablet hancur dan larut ${ }^{7}$. Persyaratan waktu larut kurang dari 5 menit dimana tablet hancur seluruhnya dan memiliki waktu larut ideal berkisar 1-2 menit 4 .

vi. Uji pH

Satu tablet effervescent dilarutkan ke dalam $100 \mathrm{~mL}$ akuades kemudian diukur menggunakan $\mathrm{pH}$ meter. $\mathrm{pH}$ larutan effervescent dikatakan baik jika mendekati normal ${ }^{8}$. 


\section{F. Analisis Data}

Uji organoleptis berupa bentuk, warna, bau dan rasa dianalisis secara deskriptif. Keseragaman bobot dianalisis mengikuti prosedur yang tercantum di Farmakope Indonesia Edisi IV, sedangkan uji kadar air, uji kekerasan, uji waktu larut dan uji pH dilakukan analisis dengan SPSS. Data yang dihasilkan dianalisis terlebih dahulu dengan Uji Shapiro Wilk untuk melihat data yang terdistribusi normal atau tidak. Data yang terdistribusi normal dilanjutkan dengan analisis ANOVA (Analysis of Variace) dengan tingkat kepercayaan 95\%. Data yang tidak terdistribusi normal dianalisis menggunakan Kruskall-Wallis.

\section{Hasil dan Pembahasan}

\section{A. Fraksi Etil Asetat buah M. casturi Kosterm}

Fraksi etil asetat yang diperoleh dari 510 gram ekstrak etanol yaitu sebesar 40,6 gram dengan persen rendemen sebesar $7,96 \% \mathrm{~b} / \mathrm{b}$.

\section{B. Evaluasi Tablet Effervescent}

1. Organoleptis

Tablet effervescent fraksi buah M.casturi secara umum berbentuk bundar dan memiliki aroma harum yang lemah. Ketiga formula memiliki rasa yang manis, hal ini dikarenakan ketiganya ditambahkan aspartam dengan jumlah yang sama. Formula 1 berwana coklat muda sedangkan formula 3 berwarna coklat tua. Hal ini dikarenakan formula 1 ditambahkan fraksi yang lebih sedikit dengan jumlah laktosa yang lebih banyak sedangkan formula 3 ditambahkan fraksi yang lebih banyak dengan jumlah laktosa yang sedikit sehingga memiliki warna yang lebih tua dari formula lainnya. Hasil penelitian disajikan pada Tabel 2 dan Gambar 1.

Tabel 2. Hasil Uji Organoleptis

\begin{tabular}{|c|l|l|l|l|}
\multirow{2}{*}{ Formula } & \multirow{2}{*}{ Warna } & \multicolumn{2}{|c|}{ Parameter } & \multirow{2}{*}{ Bentuk } \\
\cline { 3 - 5 } & & \multicolumn{2}{|c|}{ Rasa } & Bau \\
\hline 1 & Coklat muda & Manis & Harum lemah & Bundar \\
\hline 2 & Coklat & Manis & Harum lemah & Bundar \\
\hline 3 & Coklat tua & Manis & Harum lemah & Bundar \\
\hline
\end{tabular}

Formula 1 Formula 2 Formula 3

Gambar 1. Tablet effervescent fraksi etil asetat buah M. casturi

\section{2, Keseragaman bobot}

Bobot tablet effervescent fraksi buah $M$. casturi yang diharapkan dalam penelitian ini adalah $1000 \mathrm{mg}$. Nilai bobot fraksi buah $M$. casturi yang dihasilkan formula 1 berkisar antara $990-1030 \mathrm{mg}$ dengan nilai rata-rata sebesar $1010 \mathrm{mg}$, formula 2 berkisar antara 970-1020 mg dengan rata-rata sebesar $1000 \mathrm{mg}$, dan formula 3 berkisar antara 930$1020 \mathrm{mg}$ dengan rata-rata sebesar $970 \mathrm{mg}$. Berdasarkan penimbangan 10 tablet dari formula 1,2 , dan 3 tidak ada yang menyimpang dari persyaratan yang ditetapkan 
kolom A. Formula 3 memiliki tekstur yang lebih lembab diantara formula yang lain, sehingga sebagian bahan menempel pada tuangan tablet yang membuat bobot tablet kurang seragam.

\section{Kadar air}

Hasil yang diperoleh dari pengukuran kadar air tablet effervescent yaitu, untuk formula $1(4 \%)$, formula $2(5 \%)$, dan formula $3(6 \%)$ maka memenuhi persyaratan kadar air yaitu maksimum $10 \%$. Formula 3 memiliki kadar air paling tinggi, dikarenakan tingginya penambahan fraksi buah $M$. casturi yang diketahui memiliki kandungan senyawa bersifat hidrofilik yaitu mudah menyerap air sehingga dapat meningkatkan kadar air pada tablet. Berdasarkan hasil analisis statistik menggunakan metode uji KruskallWallis dari formula 1, formula 2, dan formula 3 memiliki nilai signifikansi $0,018(p<0,05)$, maka dapat disimpulkan bahwa variasi fraksi etil asetat berpengaruh terhadap kadar air tablet effervescent.

\section{Kekerasan tablet}

Evaluasi uji kekerasan tablet menunjukkan bahwa formula 3 memiliki kekerasan yang paling rendah. Hal ini disebabkan F3 memiliki tekstur lunak yang diakibatkan penambahan fraksi buah M.casturi yang cukup tinggi yaitu $500 \mathrm{mg}$. Penambahan fraksi buah $M$.casturi yang tinggi membuat kemampuan menyerap air yang dimiliki oleh tablet akan meningkat sehingga tablet yang dihasilkan menjadi lebih lunak. Hasil uji kekerasan tablet dari ketiga formula yaitu berturut-turut formula $1(8 \mathrm{~kg})$, formula 26 ( $\mathrm{kg}$ ), dan formula $3(4 \mathrm{~kg})$, maka hasil tersebut memenuhi persyaratan. Berdasarkan hasil analisis statistik menggunakan metode uji Kruskall-Wallis, kekerasan tablet ketiga formula memiliki nilai signifikansi $0,026(p<0,05)$ yang menunjukkan bahwa terdapat perbedaan yang signifikan antar formula yaitu variasi fraksi etil asetat memberikan pengaruh terhadap kekerasan tablet effervescent.

\section{Waktu larut}

Hasil uji waktu larut menunjukkan bahwa rata-rata waktu larut tablet effervescent untuk formula 1 (1,31 menit), formula 2 (2,30 menit), dan formula 3 (3,28 menit). Ketiga formula memiliki waktu larut kurang dari 5 menit maka memenuhi persyaratan waktu larut tablet effervescent ${ }^{4}$. Formula 1 memiliki waktu larut yang paling cepat sedangkan formula 3 memiliki waktu larut yang paling lama. Hal ini dikarenakan formula 3 memiliki kadar air yang lebih tinggi diantara formula lainnya yang membuat bahan effervescent bereaksi lebih awal sebelum dimasukkan ke dalam air sehingga menghasilkan waktu larut yang lebih lama diantara formula lain. Berdasarkan hasil analisis statistik menggunakan metode uji One Way ANOVA menghasilkan nilai signifikansi 0,000 $(p<0,05)$ yang menunjukkan bahwa adanya variasi konsentrasi fraksi etil asetat dengan jumlah laktosa yang berbeda memberikan pengaruh yang signifikan terhadap waktu larut tablet effervescent.

\section{6. $\mathrm{pH}$}

Pengujian $\mathrm{pH}$ menunjukkan bahwa $\mathrm{pH}$ tablet effervescent berkisar 6,4-6,5 maka hasil tersebut memenuhi persyaratan karena mendekati netral. Berdasarkan hasil analisis statistik menggunakan metode uji Kruskall-Wallis memiliki nilai signifikansi 0,670 $(p>0,05)$, dapat disimpulkan bahwa tidak ada perbedaan yang signifikan antar formula yaitu variasi fraksi etil asetat tidak berpengaruh terhadap $\mathrm{pH}$. 
Hasil evaluasi keseluruhan menunjukkan bahwa ketiga formula memenuhi persyaratan seluruh evaluasi. Formula 1 memiliki hasil paling ideal yaitu kadar air (4\%) paling sedikit diantara formula lain yang mana akan menghasilkan tablet yang lebih stabil dalam penyimpanannya. Kekerasan tablet $(8 \mathrm{~kg})$ merupakan kekerasan yang ideal untuk tablet effervescent karena jika terlalu rapuh atau lembek akan mempengaruhi stabilitas tablet tersebut. Waktu larut (1,31 menit) merupakan waktu larut yang ideal menurut Lachman et al (2008) yaitu 1-2 menit ${ }^{4}$. Oleh karena itu formula 1 dengan konsentrasi $125 \mathrm{mg}$ merupakan formula yang paling baik diantara tiga formula menurut hasil evaluasi yang telah dilakukan.

\section{Kesimpulan}

Kesimpulan penelitian ini adalah variasi fraksi etil asetat buah $M$. casturi memberikan pengaruh terhadap warna, kadar air, kekerasan tablet, dan waktu larut. Semakin besar penambahan fraksi maka semakin gelap warnanya, semakin tinggi kadar airnya, semakin lama waktu larutnya dan semakin lunak tekstur tabletnya. Formula tablet effervescent yang mengandung konsentrasi $125 \mathrm{mg}$ fraksi etil asetat merupakan tablet yang paling baik diantara formula lainnya dengan hasil evaluasi warna (coklat muda), kadar air (4\%), kekerasan tablet (8 kg), dan waktu larut (1,31 menit).

\section{Ucapan Terima Kasih}

Ucapan terimakasih kepada Ristekdikti melalui pendanaan hibah penelitian PTUPT serta semua rekan-rekan yang berperan dalam penyelesaian penelitian ini.

\section{Daftar Pustaka}

1. Sutomo. Isolasi dan Identifikasi Senyawa Penangkap Radikal DPPH dan Imunomodulator dari Buah Kasturi (Mangifera casturi Kosterm.) Suku Anacardiaceae. Desertasi Program Pascasarjana Fakultas Farmasi, Universitas Gadjah Mada, Yogyakarta. 2014.

2. Sutomo, S. Wahyuono, E.P, Setyowati, S. Rianto, \& A. Yuswanto. Antioxidant Activity Assay of Extracts and Active Fractions of Kasturi Fruit (Mangifera casturi Kosterm.) using 1, 1-Diphenyl-2-Picrylhydrazyl Method. Journal of Natural Products. 7: 2014. P. 124-130.

3. Azhari A.H. Isolasi dan Identifikasi Senyawa Antioksidan dari Buah Kasuri (Mangifera casturi Kosterm.) Skripsi Program Studi Farmasi Fakultas MIPA Universitas Lambung Mangkurat, Banjarbaru. 2016.

4. Lachman, L., H. A. Lieberman, \& J.B Schwartz. Teori dan Praktik Farmasi Fisik Volume 1 (Terjemahan). Marcel Dekker Inc, New York. 2008.

5. Depkes RI. Farmakope Herbal Indonesia Edisi Pertama. Departemen Kesehatan Republik Indonesia, Jakarta. 2008.

6. Depkes RI. Farmakope Indonesia Edisi IV. Departemen Kesehatan Republik Indonesia, Jakarta. 1995.

7. Siregar, C.J.P, \& Wikarsa, S. Teknologi Farmasi Sediaan Tablet Dasar-Dasar Praktis. Penerbit Buku Kedokteran EGC, Jakarta. 2010.

8. Rahmah, S. Formulasi granul Effervescent Campuran Ekstrak Herba Seledri (Avium graveolens) dan ekstrak daun tempuyung (Sounchus avensis L). Skripsi Farmasi FMIPA Universitas Indonesia, Depok. 2006. 